\title{
TOXICITY TESTING OF SEDIMENTS
}

\author{
OL'GA ŠESTINOVÁ, LENKA FINDORÁKOVÁ, \\ JOZEF HANČULÁK
}

\author{
Institute of Geotechnics, Slovak Academy of Sciences, Kosice, Slovak Republic \\ (sestinova@saske.sk)
}

\begin{abstract}
This study presents the results of the testing toxicity of the contaminated sediments from the water reservoir of Ružín No.I deposit (Slovak Republic) by using Phytotoxkit tests (MicroBioTests Inc., Belgium). The Phytotoxkit system is a screening tool used for a variety of toxicity testing applications. The advantages of this toxicity bioassay are its speed, relative simplicity and low cost compared to chemical analysis and many other biotests. Evaluation of sediments phytotoxicity was based on the testing of seed germination and the assesment of the root growth decrease of the plant Sinapis alba which allows to complete the assays after only 3 days of incubacion. Chemical analysis of the sediment samples involved determination of heavy metal $(\mathrm{Cu}, \mathrm{Zn}, \mathrm{Ni}, \mathrm{As}, \mathrm{Sb}$ and $\mathrm{Hg})$ concentration. No potential phytotoxic effect of heavy metals in contaminated sediments was observed in the majority of tested seeds of Sinapis alba.
\end{abstract}

Key words: phytotoxkit test, Sinapis alba, sediments, heavy metals

\section{Introduction}

The Phytotoxkit microbiotest is very flexible method to determine the impact of pollutants on higher plants and can be applied to different types of plant seeds for testing the sediments in comparison to the control soil. The effect on seed germination and root growth of mustard (Sinapis alba) in the first stadium of development is tested. Mustard root is thin; shoot is erect, hairy and up to $150 \mathrm{~mm}$ with clear green leaves. Seeds are relatively big in comparison with other Brassicaceae species, yellow or white yellow and round-shaped. They reach to $1.5-4 \mathrm{~mm}$ in diameter. After germination, the simple root with hypocotyls grows up (ZLAMALOVA GARGOSOVA et al., 2011). Phytotoxkit is the alternative test using modification of OECD 208 standards, (ISO 11269-2) Soil Quality, Method for the Measurement of Inhibition of Root Growth. Due to complex relationships, a combination of toxicological and biological assays with physicochemical data is needed to interpret and characterize contaminated sites (PLAZA, et al., 2010).

Environmental toxicity is the major problem of industrially contaminated region, where the water reservoir of the Ružín No.I is situated. Mining operations with the metallurgical processing of complex metals and copper ores left negative effects in this region. The Ružín No.I water reservoir is situated in the Hornád River. The filling process of the reservoir began in 1969. During 40 years its volume was diminished by 10 millions $\mathrm{m}^{3}$. Bottom sediments are contaminated by heavy metals, namely $\mathrm{Hg}, \mathrm{Cu}$, $\mathrm{Zn}, \mathrm{Cd}, \mathrm{Pb}, \mathrm{Cr}, \mathrm{Co}, \mathrm{Sb}$ and As. The metals present in the reservoir originate from the localities formerly used for mining activities and thus they represent ecological load mainly at the inputs into reservoir (BOBRO, 2006). Enhanced contents of heavy metals restrain direct application of sediments in agriculture, building and field 
engineering. For this reason it is important to consider their potential ecotoxicity and search for suitable ways of bottom sediments decontamination. The paper aimed to carry out the ecotoxicological bioassays of Ružin sediments and evaluate their potential ecotoxicity.

The germination is the most sensitive parameter for expression the low toxicity effects (ZUCCONI et al.. 1981; GIANNIS et al. 2008). Environmental contamination resulting from the extensive use of metals and semi-metals in industry, agriculture and in manufactured products has magnified the treat of toxicity for plants, animals and society (GIANNIS, et al., 2008; SELIM, et al., 1999). Sediments are anaerobic and in most cases the heavy metals are strongly bound as sulphides or carbonates. Sulphides are formed as a result of microbiological reduction of sulphate under anaerobic conditions. Plant activities influence the turnover of organic matter, which may have a decreasing effect on the metal ion mobility (BORTONE, et al., 2007). The different species of heavy metals show various mobility degrees, various forms of transport in water and various bioavailabilities for plants and animals as well. For example, in Hong Kong, agricultural waste, particularly pig manure, have been shown to be the major contributor to stream pollution (TIQUIA, 1996). Similarly the application of immature compost as soil fertilizer and conditioner causes negative effects on seed germination and plant growth and development, (TIQUIA, 1996; ZUCCONI, 1981).

\section{Materials and methods}

Phytotoxkit microbiotest (MicroBioTests Inc., Belgium) was performed on fresh contaminated sediments collected from the depth of 10-30 cm from the Ružin No.I water reservoir, branch of the Hornád River (1/2011 - Estuary Hornád-Hnilec) and the Hnilec River (2/2011 - Fishing house). The samples of bottom sediments were sampled into glass bottles by sample device „Multisampler“. Sampling was realized in year 2011 and total content of heavy metals (copper, zinc, nickel, arsenic, antimonite and mercury) were determined. Finally, the samples were dried, quartered, sieved under $0.1 \mathrm{~mm}$. Total heavy metal content $(\mathrm{Cu}, \mathrm{Zn}, \mathrm{Ni}, \mathrm{As}, \mathrm{Sb}$ and $\mathrm{Hg})$ in the sediments was determined after hot mineralization in a mixture of acids using the atomic absorption spectroscopy method (AAS). Three replicates were done for each sample set.

Phytotoxkit is the alternative test procedure, which allows determining the biological effect of chemical compounds on plants. The sediment was covered with the filter plate, and ten seeds of Sinapis alba were placed on top of the filter in one row. After closing the test plates with the transparent cover, the plates were placed vertically and incubated for $72 \mathrm{~h}$ at $25^{\circ} \mathrm{C}$ (Fig.1).

\section{Results and discussion}

The active sediments $\mathrm{pH}$ is presented in Table 1 . The 1/2011 and 2/2011 samples were slightly alkaline. Heavy metal contents (Table 1.) exceeded legal standards 
allowed by Law No.111/2010 (No. 188/2003) on application sludge and bottom sediment in agriculture fields) in the case of $\mathrm{As}, \mathrm{Sb}$ and $\mathrm{Hg}$.
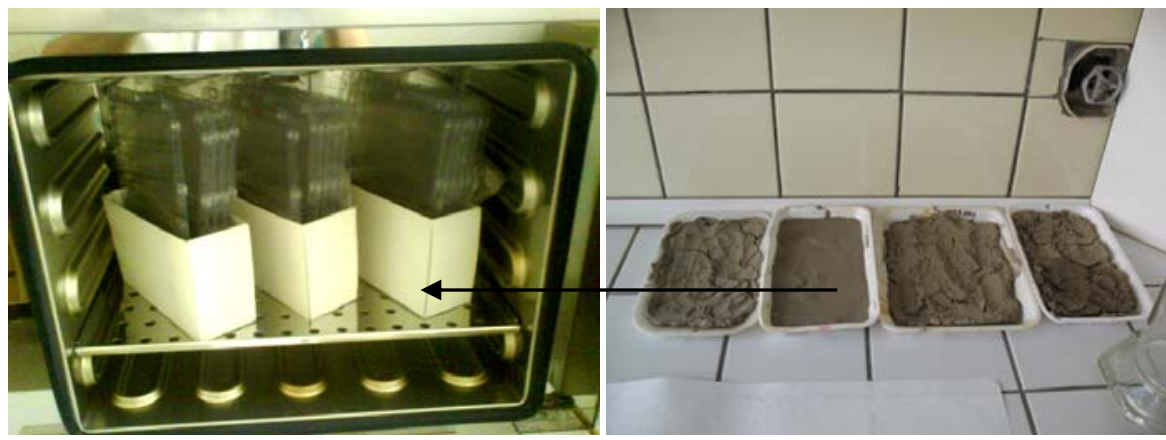

Fig. 1 Phytotoxkit test in the incubator.

The root growth inhibition was measured after 72 hours (Fig.2). The test was considered to be valid if the number of germinated seeds in control was at least $90 \%$ seeds. Pictures of the test plates (Fig.3) were analyzed with the free image analysis program (Image Tools). Evaluation of the sediment phytotoxicity was based on the decrease of seed germination and root growth of the Sinapis alba seeds in comparison to the control soil.

Table 1. Physicochemical properties of the sediment samples from the Ružin No.I water reservoir, branch of the Hornád River (1/2011 - Estuary Hornád-Hnilec) and the Hnilec River (2/2011 - Fishing house).

\begin{tabular}{ccc}
\hline Parameters: & Samples: $\mathbf{1 / 2 0 1 1}$ & $\mathbf{2 / 2 0 1 1}$ \\
Dry mass $(\%)$ & 39 & 40 \\
$\mathrm{pH}\left(\mathrm{H}_{2} \mathrm{O}\right)$ & 8 & 7 \\
ORP $(\mathrm{mV})$ & 264 & 221 \\
TOC $(\%)$ & 10 & 8 \\
\hline Total heavy metal contents & & \\
$\left(\mathrm{mg.kg}^{-1}\right)$ & 175 & 300 \\
$\mathrm{Cu}$ & 376 & 360 \\
$\mathrm{Zn}$ & 161 & 77 \\
$\mathrm{Ni}$ & 35 & 46 \\
$\mathrm{As}$ & 90 & 58 \\
$\mathrm{Sb}$ & 7 & 1 \\
$\mathrm{Hg}$ & & \\
$\left(\mathrm{mg} . \mathrm{kg}^{-1}\right)$ & 1000 & \\
$\mathrm{Cu}$ & 2500 & \\
$\mathrm{Zn}$ & 300 & \\
$\mathrm{Ni}$ & 20 & \\
$\mathrm{As}$ & - & \\
$\mathrm{Sb}$ & 10 & \\
$\mathrm{Hg}$ & &
\end{tabular}




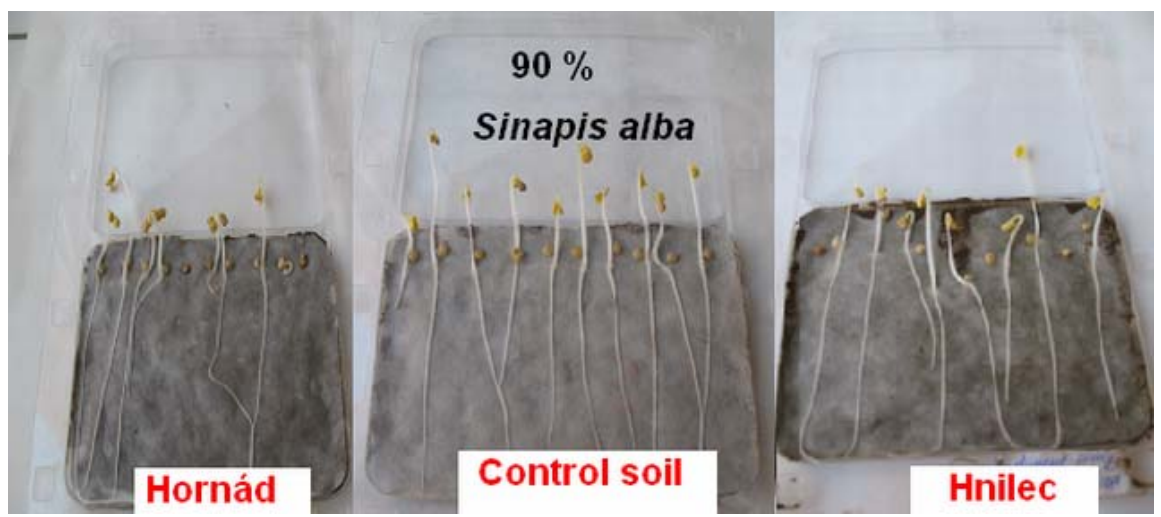

Fig. 2 Phytotoxkit microbiotest - a comparison of seed germination in the samples 1/2011 (branch of the Hornád River ) and 2/2011 ( branch of the Hnilec River ) with control soil.

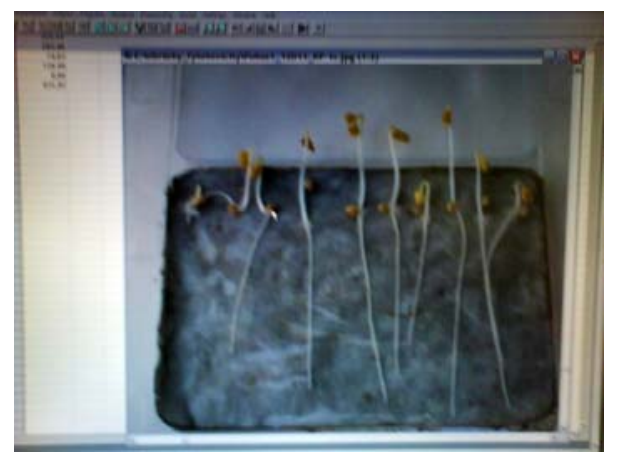

Fig. 3 Calibration of length measurements ( in $\mathrm{mm}$ ) of the germinated seeds, program (Image Tools).

The sediment samples were used to evaluate the potential phytotoxic effect using the parameters - percentage inhibition of seed germination (ISG) and percentage inhibition of root growth (IRG) in test sediment:

$$
\begin{gathered}
I S G(\%)=\frac{\text { number of seeds germinated in CS }- \text { number of seeds germinated in sediment }}{\text { number of seeds germinated in CS }} \times 100 \\
I R G(\%)=\frac{\text { mean root length in CS (in } \mathrm{mm})- \text { mean root length in sediment (in } \mathrm{mm})}{\text { mean root lenght in CS }(\text { in } \mathrm{mm})} \times 100
\end{gathered}
$$

where CS represents control soil.

The percentage inhibition of seed germination (ISG) was $11.5-33.1 \%$ and $12.5-$ $33 \%$ in the 1/2011-Hornad and 2/2011- Hnilec samples, respectively. The percentage of the inhibition of root growth (IRG) was higher in comparison with the inhibition of seed germination. It was $10.2-25.2 \%$ and $18.6-42.5 \%$ in the $1 / 2011$ - Hornád and 
2/2011- Hnilec sediments, respectively (Figure 4-5). Over $90 \%$ of seeds in control samples were germinated. According to the Phytotoxkit microbiotest the experimental concentration in which growth inhibition is tightly above $50 \%$ after 72 hours can be considered to be effective concentration $72 / \mathrm{EC}_{50}$. Both the inhibitions of germination rate were not much different from the controls.

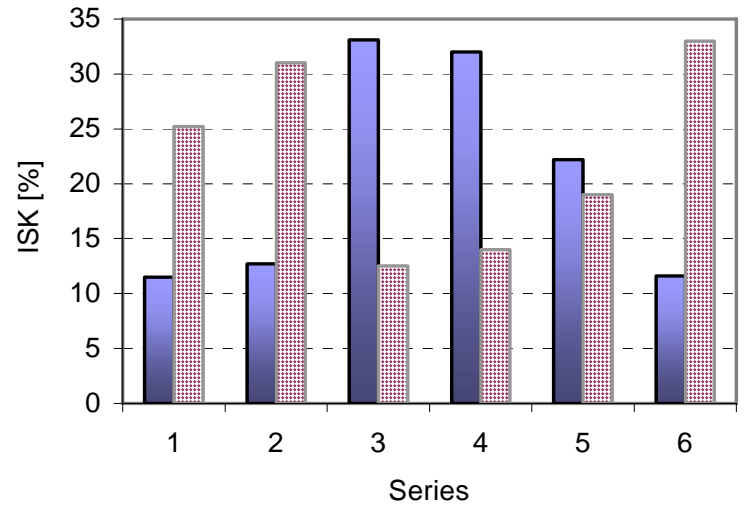

$\square$ Hornád $\mathrm{B}$ Hnilec

Fig. 4. The inhibition of seed germination (ISG \%) of the Sinapis alba in the six series of sediments.

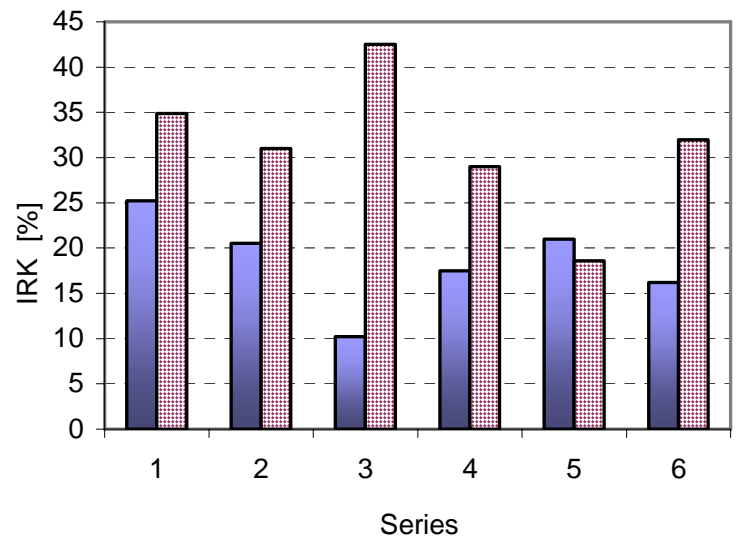

$\square$ Hornád $\square$ Hnilec

Fig. 5. The inhibition of root growth (IRG \%) of the germinated seeds of the Sinapis alba in the six series of sediments.

\section{Conclusions}

The seed germination and root elongation technique was used because it is an easy and inexpensive screening test. Based on the experimental results of the phytotoxicity 
testing no potential phytotoxic effect of heavy metal contaminated sediments from Ružin No.I water reservoir on tested Sinapis alba seeds was observed. According to the assays carried out it was found that even 1.5 - 2 times higher $\mathrm{As}, \mathrm{Sb}$ and $\mathrm{Hg}$ concentrations in sediments in comparison with legal standards did not have phytotoxic effects on tested Sinapis alba seeds.

Acknowledgement: This work was supported by the Slovak Research and Development Agency (No 0252-10, No -51-02 7705) and by the Slovak Grant Agency for Science VEGA (grant No- 2/0187/11).

\section{References}

BOBRO, M.: Záverečná správa z prieskumu kvality a kvantity nánosov a eróznych procesov v povodí Hornádu a Hnilca po priehradný profil VD Ružín I v r. 20022005, Košice, Ústav geotechniky SAV, 2006 (in Slovak).

BORONE, G., PALUMBO, L.: Sustainable management of sediment resources. Sediment and Dredged Material Treatment, Elsevier, Vol. 2, 2007, 207 pp.

GIANNIS, A., GIDARAKOS, E., SKOUTA, A.: Transport of cadmium and assessment of phytotoxicity after electrokinetic remediation. J. Environ. Manage., $86,2008,535-544$.

PLAZA, G.A., JAWECKI, G.N., PINYAKONG, O., ILLMER, P., MARGESIN, R.: Ecotoxicological and microbiological characterizatio of soils from heavy-mataland hydrocarbon- contaminated sites. Environ. Monit. Assess., 163, 2010, 477488.

SELIM, H. D., ISKANDAR, I. K.: Fate and Transport of Heavy Metals in the Vadose Zone. Lewis Publishers, Florida, 1999.

TIQUIA, S. M., TAM, N. F Y., HODGKISS, I. J .: Effects of composting on phytotoxicity of spent pig-manure awdust litter. Environ. Pollut., 93, 1996, 249256.

ZLAMALOVA GARGOSOVA, H., VAVROVA M., DOLEZALOVA WEISSMANNOVA, H., MRAVCOVA, L., VYDROVA, L., ZOUHAR, L.: The use of methods of environmental analysis and ecotoxicological tests in the evaluation of wastewater. Waste Water-Evaluation and Management. Rijeka, Croatia: InTech, 2011, 3-30.

ZUCCONI, F., FORTE, M., MANOCO, M., BERTOLDI, M.: Biological evaluation of compost maturity. Bio Cycle, 22, 1981, 27-29.

Presented at the 2nd International Conference "Biotechnology and Metals - 2011", September 22-23, 2011, Košice, Slovak Republic. 